\title{
Hubungan Asupan Zat Besi dengan Status Anemia pada Santri Putridi Pondok Pesantren Hidayatussalikin Air Itam Kota Pangkalpinang Tahun 2017
}

\author{
Emilia \\ Jurusan Gizi, Poltekkes Kemenkes Pangkalpinang \\ Email Korespondensi :emiliagizi73@gmail.com
}

\begin{abstract}
Abstrak
Menurut hasil Riskesdas 2013 prevalensi anemia kekurangan zat besi paling banyak terjadi pada remaja putri, yaitu sebesar 22,7\%.Anemia yang paling umum terjadi pada remaja putri adalah karena produksi sel-sel darah merah tidak mencukupi yang disebabkan oleh asupan makanan sumber zat besi yang kurang. Tujuan penelitian ini adalah menilai hubungan asupan zat besi dengan status anemia pada santri putri di Pondok Pesantren Hidayatussalikin Kota Pangkalpinang. Jenis penelitian ini adalah observasional dengan rancangan cross sectional. Besar sampel 50 diambil secara purposive.Subjek penelitian ini adalah santri putri di Pondok pasantern Hidayatussalikin Pangkalpinang yang memenuhi criteria inklusi tidak sedang sakit dan menstruasi. Data dianalsis secara deskriftif dalam bentuk tabel frekuensi dan di uji secara statistik menggunakan uji chi square. Hasilpenelitian responden dengan asupan zat besi kurang berstatus anemia sebsar 73,5\%, sedangkan responden dengan asupan zat besi baik berstatus anemia sebesar 11,1\%. Hasil uji statistic di peroleh nilai $p=0,001$. Kesimpulan : Ada hubungan asupan makanan sumber zat besi dengan kejadian anemia pada remaja putri.
\end{abstract}

Kata kunci : Asupan Zat Besi, Status Anemia, Remaja Putri

\section{The Relationship between ron Intake and Anemia on Female Students At Hidayatussalikin Islamic Boarding School in Air Itam Pangkalpinang 2017}

\begin{abstract}
According to the 2013 Riskesdas results, the prevalence of iron deficiency anemia has mostly occurred in young women, which was $22.7 \%$. Anemia that is very common in young women is due to inadequate production of red blood cells, which is caused by insufficient intake of iron sources. The purpose of this study was to convey the relationship between iron intake and anemia on female students at Hidayatussalikin Islamic Boarding School in Pangkalpinang. The type of research was observational with a cross-sectional design. The sample size was 50 and it was taken purposively. The subjects of this study were female students at Hidayatussalikin Islamic Boarding School Pangkalpinang who had met the inclusion criteria that they were not sick and menstruating. Data were analyzed descriptively in the form of frequency tables and statistically tested using the chi-square test. The results of the study were obtained from respondents who did not have enough iron intakes and had anemia which was $73.5 \%$, while respondents with adequate iron intake and anemia were $11.1 \%$. The results of the statistical test were obtained p-value $=\mathbf{0 . 0 0 1}$. Conclusion: There is a relationship between iron-containing foods and cases of anemia among young women.
\end{abstract}

Keywords :Iron Intake, Anemia status and female students 


\section{PENDAHULUAN}

Prevalensi anemia secara global di dunia sebesar50\%, dan 36\% terdapat di Negara berkembang (Arisman, 2010).Indonesia sebagai salahsatu negara berkembang, kejadian anemia masih cukup tinggi.Menurut hasil Riskesdas tahun 2013prevalensi anemia defisiensi besibanyak ditemukan pada remaja putri, yaitu sebesar $22.7 \%$, sedangkan anemia defisiensi besi pada remaja laki - lakisebesar $12.4 \%$ (Kemenkes RI,2014).Data Survei Kesehatan Rumah Tangga (SKRT) tahun 2012 dengan rincian yaitu prevalensi anemia pada balita sebesar 40,5\%, ibu hamil sebesar 50,5\%, ibu nifas sebesar $45,1 \%$, remaja puteri usia $10-18$ tahun sebesar $57,1 \%$, dan usia 19-45 tahun sebesar 39,5\%.Berdasarkan data diatas dapat dilihat kelompok remaja yang paling tinggi mengalami anemia terutama remaja putri.

Secara umum tingginya prevalensi anemia gizi besi antara lain disebabkan oleh beberapa faktor yaitu kehilangan darah secara kronis, asupan zat besi tidak cukup dan peningkatan kebutuhan akan zat besi (Arisman, 2004).Kasus anemia yang tersebar di seluruh dunia secara langsung 50\% disebabkan kurangnya masukan (intake) zat besi (Dillon, dalam Arumsari, 2008).

Banyaknya remaja putri yang menderita anemia, hal ini disebabkan karena remaja putri memiliki siklus menstruasi setiap bulannya dan pada umumnya memiliki karakteristik kebiasaan makan tidak sehat. Kebiasaan tidak makan pagi, malas minum air putih, diet tidak sehat karena ingin langsing, kebiasaan ngemil makanan rendah gizi dan makan makanan siap saji, sehingga remaja putri tidak mampu memenuhi keanekaragaman zat makanan yang dibutuhkan oleh tubuhnya untuk proses sintesishemoglobin $(\mathrm{Hb})$. Bila hal ini terjadi dalam jangka waktu yang lama, maka akan menyebabkan kadar $\mathrm{Hb}$ terus berkurang dan menimbulkan anemia (Andriani dan Wirjatmadi, 2013 ).

Beberapa penelitian mengenai kejadian anemia pada remaja putri, khusus nya di pondok pasantren cukup tinggi.Hasil penelitian
Farida (2006) menunjukkan ada hubungan asupan zat besi dengan kejadian anemia pada remaja putri di pondok pasantren(pvalue $<0,05)$.Penelitian

Retnoningsih (2004) menujukkan kejadian anemia pada remaja putri di pondok pasantren sebesar 36,8\%. Penelitian yang dilakukan Dewi (2011) dalam Is Rinieng Nur Sya`Bani (2016) di Pondok Pasantren Al-Islam Nganjuk terdapat $97 \%$ responden yang merupakan santriwati defisit zat besi.

Remaja putri yang tinggal dipondok pasantren dikenal dengan nama santriwati, usia mereka berkisar antara 11- 18 tahun. Tingginya prevalensi anemia gizi besi terutama pada remaja putri dan setelah sekian lama program anemia gizi dijalankan namun kasus anemia masih cukup tinggi dan tidak kunjung menurun, dan terkait denganbeberapa penelitian pada santriwati di Pondok Pasantren dengan kasus anemia cukup tinggi,sehingga penulis tertarik untuk melakukan penelitian tentang hubungan asupan zat besi dengan status anemia pada Santriwati di Pondok Pasantren Hidayatussalikin Pangkalpinang.

\section{METODE}

Jenis penelitian yang digunakan adalah deskriptif analitik, menggunakan metode survey dengan desain cross-sectional. Penelitiandilaksanakan

diPasantrenHidayatussalikinAir ItamKota Pangkalpinang pada bulan mei tahun 2017. Parameter yang akan diamati dalam penelitian ini terdiri dua variabel yaitu, variabel dependen adalah status anemia diukur kadar hemoglobin dengan menggunakan hemocue,sedangkan variabel independen adalah asupan zat besi yang diukur dengan cara wawancaramenggunakanmetodefood recall 24 jam.

Populasi adalah santri putri di Pondok Pesantren Hidayatussalikin berjumlah 80 orang yang dilakukan secara purposive, yaitu dengan pertimbangan pemilihan lokasi penelitian didasarkan atas : 
1. Resiko anemia yang terjadi pada remaja putrid atau santri putri

2. Diasumsikan Adanya kesamaan frekuensi jenis makanan santri putri

3. Penelitian sejenis belum pernah dilakukan di lokasi tersebut

Kriteria inklusi dan eksklusi pada penelitian iniadalah :

Kriteria inklusi

1. Santri putri usia $12-18$ tahun.

2. Santri putri sudah mengalami haid atau menstruasi.

3. Bersedia menjadi peserta penelitian

Kriteria Ekslusi

1. Pada saat dilakukan pemeriksaan kadar hemoglobin $(\mathrm{Hb})$ sedang mengalami menstruasi.

2. Mengkonsumsi suplemen zat besi

3. Mengalami penyakit infeksi kronis, seperti malaria, TBC, kecacingan.

Jumlah sampel minimalsebanyak58 orang diambil berdasarkan rumus menggunakan proporsi populasi (prevalensi anemia sebesar $51 \%$ ), dengan tingkat kepercayaan $95 \%$ (Rachmat, 2012)

Analisisdata melalui dua tahap:

1. Analisis univariat

Data diolah secara statistik deskriptif ,yaitu untuk mengetahui distribusi frekuensi dan proporsi masing-masing variabel, sehingga diketahui gambaran rata-rata kadar $\mathrm{Hb}$, status anemia dan asupan zat besi responden

2. Analisis bivariat

Untuk melihat hubungan asupan zat besi dengan kejadian anemia pada responden, yang diuji secara statistikmenggunakan uji chi square.

\section{HASIL}

1. Analisis Univariat

Dari seluruh sampel santri putri yang diperiksa kadar hemoglobin dalam darah dapat dilihat hasilnya dalam tabel berikut ini:
Tabel 1.Rata-rata Kadar Hemoglobin Santri Putri

\begin{tabular}{ccccc}
\hline Variabel & $\begin{array}{c}\text { Mean } \\
\text { Median }\end{array}$ & SD & $\begin{array}{c}\text { Min- } \\
\text { Max }\end{array}$ & $\mathbf{9 5 \% C I}$ \\
\hline Hemoglobin & 11,91 & & $8,9 \pm$ & $10,86 \pm 11,52$ \\
& 11,50 & 1,25 & 13,5 & \\
& &
\end{tabular}

Rata-rata kadar $\mathrm{Hb}$ santri putri adalah 11,91 gr/dl dengan median 11,50 gr/dl. Kadar Hb terendah 8,9 $\mathrm{gr} / \mathrm{dl}$ dan tertinggi 13,5 gr/dl. Hasil estimasi interval dapat disimpulkan bahwa $95 \%$ diyakini rata-rata kadar $\mathrm{Hb}$ santri putri berada diantara 10,86 gr/dl $11,52 \mathrm{gr} / \mathrm{dl}$.

Tabel 2. Rata-rata Asupan Zat Besi Santri Putri

\begin{tabular}{ccccc}
\hline Variabel & $\begin{array}{c}\text { Mean } \\
\text { Median }\end{array}$ & SD & $\begin{array}{c}\text { Min } \\
\text { Max }\end{array}$ & $\mathbf{9 5 \%}$ CI \\
\hline Asupan & 27.17 & & $10.9 \pm 4$ & $25.00 \pm 29.33$ \\
Zat besi & 27.27 & 8.23 & 1.3 &
\end{tabular}

Rata-rata asupan zat besi santri putri adalah 27,17 gr, dengan median 17,27 gr. Asupan zat besi terendah 10,9 gr dan tertinggi 41,31gr. Hasil estimasi interval dapat disimpulkan bahwa 95\% diyakini rata -rata asupan zat besi santri putri berada diantara $.25,00$. gr - 29,33 gr

Tabel .3.Status Anemia Santri Putri

\begin{tabular}{|c|c|c|c|}
\hline \multirow{2}{*}{ No. } & \multirow{2}{*}{ Kategori } & \multicolumn{2}{|c|}{ Jumlah } \\
\hline & & $\mathbf{n}$ & $\%$ \\
\hline 1. & Anemia $\quad(\mathrm{Hb}<12 \mathrm{~g} / \mathrm{dl})$ & 37 & 63,8 \\
\hline 2. & Tidak Anemia $(\mathrm{Hb} \geq 12 \mathrm{~g} / \mathrm{dl})$ & 21 & 36,2 \\
\hline & Total & 58 & 100 \\
\hline
\end{tabular}

Tabel 3 menunjukkan status anemia santri putri,diketahui bahwa $37(63,8 \%)$ mengalami anemia dan 21(36,2\%) tidak anemia.

Tabel 4. Asupan Zat Besi Santri Putri

\begin{tabular}{|c|c|c|c|c|}
\hline \multirow{2}{*}{ No. } & \multirow{2}{*}{\multicolumn{2}{|c|}{ Kategori }} & \multicolumn{2}{|c|}{ Jumlah } \\
\hline & & & $\mathbf{n}$ & $\%$ \\
\hline 1. & Kurang & $(<80 \% \mathrm{AKG})$ & 49 & 84,5 \\
\hline \multirow[t]{2}{*}{2.} & Baik & $(\geq 80 \%$ AKG) & 9 & 15,5 \\
\hline & & Total & 58 & 100 \\
\hline
\end{tabular}

Tabel 4. Menunjukkan asupan zat besi santri putri, jika dibandingkan dengan Angka Kecukupan Gizi (AKG) yang dianjurkan, diketahui bahwa $49(84,5 \%)$ adalah kurang dan $9(15,5 \%)$ adalah baik. 
2. Analisa Bivariat

Tabel 5.Hubungan Asupan Zat Besi dengan Status Anemia Santri Putri

\begin{tabular}{|c|c|c|c|c|c|c|c|c|c|}
\hline \multirow[t]{3}{*}{ No. } & \multirow{3}{*}{$\begin{array}{l}\text { Asupan } \\
\text { zat besi }\end{array}$} & \multicolumn{6}{|c|}{ Status Anemia } & \multirow[t]{3}{*}{ OR } & \multirow[t]{3}{*}{ P* } \\
\hline & & \multicolumn{2}{|c|}{ Anemia } & \multicolumn{2}{|c|}{$\begin{array}{c}\text { Tidak } \\
\text { Anemia }\end{array}$} & \multicolumn{2}{|c|}{ Total } & & \\
\hline & & $\mathrm{n}$ & $\%$ & $\mathrm{n}$ & $\%$ & $\mathrm{n}$ & $\%$ & & \\
\hline 1. & Kurang & 36 & 73,5 & 13 & 26,5 & 49 & 100 & 22 & $\begin{array}{c}0,00 \\
1\end{array}$ \\
\hline 2. & Baik & 1 & 11,1 & 8 & 88,9 & 9 & 100 & & \\
\hline & Total & 37 & 63,8 & 21 & 36,2 & 58 & 100 & & \\
\hline
\end{tabular}

Hasil analisis hubungan antara asupan zat besi dengan status anemia diperoleh $36(73,5 \%)$ santri putri yang asupan zat besi kurang mengalami anemia, sedangkan 1 dari $9(11,1 \%)$ asupan zat besi baik mengalami anemia. Hasil uji statistik diperoleh nilai $\mathrm{p}=0,001$, maka dapat disimpulkan ada perbedaan proporsi asupan zat besi kurang terhadap status anemia, dengan nilai $\mathrm{OR}=22$, hal ini menunjukkan bahwa santri putri yang asupan zat besinya kurang mempunyai peluang 22 kali mengalami anemia

\section{PEMBAHASAN}

Hasil analisa data diketahui bahwa ratarata kadar hemoglobin santri putri adalah rendah, yaitu $11,50 \mathrm{gr} / \mathrm{dl}$, dari 58 responden yang ada sebanyak 37 orang $(63,8 \%)$ yang mengalami anemia. Menurut Arisman (2009) remaja putri membutuhkan paling banyak zat besi karena digunakan untuk pertumbuhan dan pematangan organ seksual serta untuk menggantikan zat besi yang terbuang pada saat haid. Lailiyana (2010) juga mengemukakan, bahwa berdasarkan karakteristik remaja pada rentang usia $12-18$ tahun kebutuhan zat gizi meningkat terutama adalah energi, protein, kalsium, besi, dan zinc.

Asupan dan kualitas makanan yang baik sangat mempengaruhi kesedian gizi bagi remaja (Moehji S,2017). Pada penelitian ini dilakukan wawancara menggunakan metode recall makan 24 jam selama 3 hari dimana pengambilan data recall makan dilaksanakan pada hari saat santri mendapatkan makanan di asrama, saat setelah santri pulang kerumah dan saat santri dibebaskan untuk keluar pondok dihari weekand. Hasil analisa data, rata-rata asupan makanan sumber zat besi santri putri adalah 27,17 gr/hari, dari 58 santri putri yang menjadi responden terdapat 49 orang $(84,5 \%)$ dengan asupan zat besi kurang Menurut Angka Kecukupan Gizi yang dianjurkan ( Kemenkes, 2013) kebutuhan zat besi bagi remaja putri sebesar 40 gr/hari. Hasil Penelitian ini dipengaruhi dengan kurangnya asupan lauk pauk merupakan makanan sumber zat besi sedangkan zat besi mempunyai peran penting untuk pembentukan hemoglobin (Al Mousa, dkk dalam Adhisti, 2011).Protein berperan penting dalam transportasi zat besi di dalam tubuh. Oleh karena itu, kurangnya asupan protein akan mengakibatkan transportasi zat besi terhambat sehingga akan terjadi defisiensi besi. Makanan yang tinggi protein terutama yang berasal dari hewani banyak mengandung zat besi.Tingkat konsumsi protein perlu diperhatikan karena semakin rendah tingkat konsumsi protein maka semakin cenderung untuk menderita anemia (Afian dalam Kirana, 2011).

Hasil analisa perencanaan siklus menu 7 hari yang diselenggarakan di Pasantren Hidayatussalikin, dapat diketahui dari penelitian yang dilakukan bersama dengan penelitian ini rata-rata asupan protein remaja putri sebesar 42,63 gr/hari, hal ini jelas masih sangat kurang dari Angka kecukupan Gizi (AKG) yang dianjurkan yaitu untuk remaja putri sebesar 60 gr/hari (Kemenkes , 2013).

Bahan makanan yang merupakan sumber zat besi yaitu makanan hewani sebagai sumber zat besi heme (daging, ikan) atau bahan makanan yang mengandung hemoglobin dan mioglin yang mudah diserap oleh tubuh.Sedangkan makanan nabati sebagai sumber zat besi non heme mempunyai sifat sangat sedikit diabsorbsi oleh tubuh (Gibney M, et al, 2009) Disamping itu masih banyaknya zat penghambat absorbsi zat besi yang dikonsumsi seperti asam fitat, serat makan dan tanin, serta sangat rendah konsumsi zat sebagai promoters absorbsi zat besi (Heather, A E dan Miller, A. $C$, 2009).Masalah anemia gizi yang disebabkan kekurangan besi merupakan masalah gizi utama di Indonesia. Anemia kekurangan besi terjadi 
karena pola konsumsi makanan masyarakat di Indonesia masih di dominasikan sayuran sebagai sumber zat besi yang sulit diserap sedangkan daging dan makanan sumber heani sebagai sumber besi yang baik dikonsumsi dalam jumlah yang kurang ( Farida, 2007)

Hasil uji statistik Chi-Square nilai $\mathrm{p}=0,001$ hal ini menunjukkan bahwa ada beda proporsi kejadian anemia antara santri putri dengan asupan zat besi yang kurang dan asupan zat besi yang baik, yang berati ada hubungan yang signifikan antara asupan zat besi dengan status anemia pada santri putri di Pondok Pesantren Hidayatussalikin Air Itam Kota Pangkalpinang, dimana OddRasio sebesar 22 dari penelitian ini dapat dijelaskan bahwa santri putri yang mengalami anemia dengan asupan zat besi kategori kurang 22 kali memiliki resiko menderita anemia dibandingkan dengan asupan zat besi kategori baik.

Penelitian ini sejalan dengan penelitian Farida (2006) faktordeterminan( Protein dan vitamin C ) kejadian anemia pada remaja putri Kecamatan Gebong Kabupaten Kudus $(\mathrm{p}=0.001)$. dan sejalan dengan penelitian Kirana (2011) Hubungan Asupan zat gizi (Kalori, protein dan vitamin C) dan pola menstruasi dengan kejadian anemia pada remaja putri di SMA N 2 Semarang $(p=0,000)$.

\section{SIMPULAN}

Berdasarkan hasil dan pembahasan diatas maka dapat disimpulkan bahwa Asupan zat besisantri putri di Pondok Pesantren Hidayatussalikin Air Itam Pangkalpinang kategori kurang $(<80 \%$ AKG) sebanyak 84,5\%. Prevalensi kejadian anemia pada santri putri di Pondok Pesantren Hidayatussalikin Air Itam Pangkalpinang yaitu sebesar $63,8 \%$. Ada hubungan antra asupan zat besi dengan status anemia santri putri di Pondok Pesantren Hidayatussalikin Air Itam Pangkalpinang yang ditunjukkan dengan hasil statistik chi-square dengan nilai $\mathrm{p}=0,001$.

\section{SARAN}

Perlu adanya evaluasi sistem penyelenggaraan makanan pondok pesantren tersebut. Perlu adanya peningkatan asupan zat besi dan protein. Perlu adanya pengadaan penyuluhan gizi khusunya melalui dinas terkait tentang anemia dan makanan kaya zat besi.

\section{UCAPAN TERIMA KASIH}

Telah dilaksanakan Penelitian ini tak lupa penulis mengucapkan terimakasih kepada pihak pasantren Hidayatussalikin yang memfasiliatasi dalam pengumpulan data sehingga berjalan dengan lancar dan tak lupa ucapan terimakasih peneliti kepada pihak review artikel JKP yang ikut membantu dalam kelayakan artikel penelitian ini untuk dapat diterbitkan.

\section{DAFTAR PUSTAKA}

Andriani, M dan Wirjatmadi, B (2013)Peranan Gizi Dalam Siklus Kehidupan.Jakarta : Kencana Prenada Media Group

Adhisti, P, A. (2011). Hubungan Status Antropometri dan asupan Gizi Dengan Kadar Hb Dan Feritin Remaja Putri Di Pondok Pesantren At - Taqwa Semarang : Tesis

Albalak, R. (2001). Pemaparan Timbal Dan Anemia Pada Anak-Anak Di Jakarta Indonesia : Tesis.

Almatsier, S. (2004).Prinsip Ilmu Gizi.Jakarta : PT. Gramedia Pustaka Utama.

Arisman.(2010). Gizi Dalam Daur Kehidupan.Jakarta : Penerbit Buku Kedokteran, EGC.

Arumsari, E. (2008). Faktor Resiko Anemia Pada Remaja Putri Peserta Program Pencegahan Dan Penanggulangan Anemia Gizi Besi (PPAGB) di Kota Bekasi : Tesis. 
Djaeni Achmad. (2000). Ilmu Gizi Untuk Mahasisa Profesi Di Indonesia.Jakarta : Dian Rakyat.

Farida, I. (2006). Determinan Kejadian Anemia Pada Remaja Putri di Kecamatan Gebong Kabupaten Kudus : Tesis.

Gibney M, Margetts M, Kearney J, Arab L,.(2009). Gizi Kesehatan Masyarakat.Jakarta : Penerbit Buku Kedokteran EGC.

Gunatmaningsih, D. (2007). Faktor-Faktor Yang Berhubungan Dengan Kejadian Anemia Pada Remaja Putri di SMAN 1 Kecamatan Jati Barang Kabupaten Brebes : Skripsi.

Heather A Eicher dan Miller, A. C. 2009.Food insecurity is associated withiron deficiency anemia in USAldolescents. Am J Clin Nutr,90:1358-71

Iryani.I. (2001).Hubungan Perilaku Gizi (Anemia), Tingkat Konsumsi (Protein Dan Zat Besi) Dan Status Gizi (BB/TB) Dengan Kadar Hb Siswi SMA Negeri I Dempet Kecamatan Kabupaten Demak Provinsi Jawa Tengah: Skripsi.

Kementerian Kesehatan RI Direktorat Jenderal Bina Kesehatan Masyarakat.(2010). Rencana Aksi Pembinaan Gizi Masyarakat 2010 - 2014.Jakarta : Kementerian Kesehatan RI.

Kirana, D. P. (2011).Hubungan Asupan Zat Gizi dan Pola Menstruasi Dengan Kejadian Anemia Pada Remaja Putridi SMAN 2 Semarang : Skripsi.

Manampiring, A, E. (2008).Prevalensi Anemia Dan Tingkat Kecukupan Zat Besi Anak Sekolah Dasar Di Desa Minaesa Kecamatan Wori Kabupaten Mihasa Utara : Tesis.
Muchtar, M. (2000).Status Anemia dan Prestasi Belajar Sisi SMUN 1 Kuala Kapuas : Skripsi.

Nursari, D. (2009). Gambaran Kejadian Anemia Pada Remaja Putri SMP Negeri 18 Kota Bogor Tahun 2009 : tesis.

Puspitasari, F. (2008).Pengaruh Faktor Individu, Keluarga dan Sekolah Terhadap Prestasi Belajar : Skripsi.

Rachmat, M. (2011).Buku Ajar Biostatistika.Jakarta : Penerbit Buku Kedokteran EGC.

Riset Kesehatan Dasar.(2013). Badan Penelitian Dan Pengembangan Kesehatan Departemen KesehatanRI.Jakarta.

Syafiq. A, Setiarini A, Mulyaati D, Fatmah, Sartika, R.A.D, Fikawati. S. (2007).Gizi dan Kesehatan Masyarakat.Jakarta : Raja Grafindo Persada.

Safry, M, Sirajuddin. S, Tawali, A. (2013). Hubungan Faktor Keluarga Dan Anak Dengan Kejaidan Anemia Pada Anak Sekolah Dasar Inpres Cilallang Kota Makassar Tahun 2013 : Tesis.

Supriasa, dkk.(2002). Penilaian Status Gizi.Jakarta : Penerbit Buku Kedokteran EGC.

Supriasa, dkk.(2011). Penilaian Status Gizi.Jakarta : Penerbit Buku Kedokteran EGC.

Tan, Anthony. (1996). Anita dan Nutrisi.Jakarta : Bumi Asih. 